\title{
The effect of processing on digestion and utilization of cereals by ruminants
}

By E. R. Ørskov, Rowett Research Institute, Bucksburn, Aberdeen AB2 $9 S B$

It is unlikely that the cereal grain used for cattle feeding has ever been given to any great extent in the whole unprocessed form. The early literature would suggest that grain was processed both for the destruction of hard seeds from weeds and for aiding digestion. In an old encyclopedia (Morton, $18_{55}$ ), it is concluded that 'the more thorough the artificial digestion of the cereals (grinding and boiling) the more perfect will be its natural digestion and consequent utilization in the system of the animal'. Later on, however, it seems that some modification to that view had taken place. While Kellner (1908) concludes that maize, barley, rye and wheat must be processed for all animals, he specifically uses the term 'roughly ground' as being preferable to finely ground. The same recommendation was made by Armsby (1917) that fine grinding was undesirable. He also refers to an experiment by Gay (1896) who gave one sheep $500 \mathrm{~g}$ of oats, crushed or whole, and observed that crushing made no difference to its digestibility. There is a dearth of early information on sheep, but Morrison (1948) concludes 'in general sheep chew their food the most efficiently of all larger farm animals', and goes on to state that there should be no need for processing of cereals for that species. The observation leading to this conclusion is not specified.

It is not intended to review in detail production aspects of mechanical processing and sites of fermentation since many excellent reviews have appeared on this subject, notably Waldo (1973), Armstrong (1972, 1974), Hale (1973) and Burt (1973). Instead, an attempt will be made to review in more detail how processing of cereal grain influences digestion in the rumen both when cereal diets are given as virtually sole foods and when they are given as supplements to roughage-based diets.

The use of cereal-based diets for ruminants has recently received severe criticism on the grounds that cereals could be directly utilized by man. It should be remembered that for ruminants in the UK, cereals are mainly grown as winter foods on arable land in competition with other sources of winter food such as silage, hay or root crops. It would seem difficult to argue that cereals should not be used if it was economical to do so, unless it is argued also that no arable land should be used for the production of winter food to sustain animal production.

\section{Effect of processing on type of fermentation, digestibility and food utilization}

Since the amount of processing required is different for different species it has been found most convenient to consider sheep and goats in separation from cattle. 


\section{Sheep and goats}

Morrison's (1948) statement that sheep can digest whole grains, which was mentioned above, is repeated in later editions of his book Feeds and Feeding, but cereal-based supplements for sheep have generally been ground and pelleted. The development of cereal-based diets as sole feedstuffs for early weaned lambs (Philip, Preston \& Greenhalgh, 1964; Andrews \& $\emptyset$ rskov, 1970) was based on pelleted, rolled barley, since this had been successful for cattle (Preston, 1963), and as far as food utilization was concerned, it was very successful. The food conversion ratio ( $g$ food dry matter (DM) intake/g live-weight gain) during the fattening period of Suffolk $\times$ Scottish Halfbred lambs was 2.22 and 2.33 for pelleted diets based on kibbled maize and rolled barley respectively, with growth rates of $430 \mathrm{~g} / \mathrm{d}$ (Ørskov, Fraser, Gill \& Corse, I97I). While hypertrophy of the rumen wall was prevalent it was not found to be associated with any extent of inflammatory reactions as in cattle (Fell, Kay \& Walker, 1967). This species difference was found to be due to the consumption by cattle of hairs which penetrated the epithelial layers of the rumen wall (Fell, Kay, Ørskov, Boyne \& Walker, 1972). Although wool was occasionally consumed by sheep it was found not to cause this problem. Inflammatory reactions similar to those found in cattle were found in the rumen wall of lambs which had been given cattle hairs mixed in their food (Fell et al. 1972). Bloat problems were never encountered. However, while food utilization was satisfactory, the system of feeding on grain suffered from a very serious shortcoming; the lamb carcasses were unacceptable to the meat trade. The subcutaneous fat was too soft and on analysis contained a large proportion of oddnumbered and monomethyl-branched-chain fatty acids. These branched-chain acids and the associated reduction in the stearic acid content were responsible for the altered melting point of the fat (Duncan, Ørskov \& Garton, 1972).

The involvement of methylmalonic acid, which is an intermediate in propionic acid metabolism, was suspected and discussed (Duncan et al. 1972, Duncan, Ørskov, Fraser \& Garton, 1974) and later shown unequivocally (Scaife \& Garton, 1975). It was first considered that the problem occurred as a result of a relative deficiency of vitamin $B_{12}$ since this vitamin is a cofactor in the conversion of methylmalonic acid to succinic acid; however, frequent injections of hydroxocobalamin or of cyanocobalamin had no effect (Duncan et al. 1974).

It seemed that intensive feeding systems for early weaned lambs would need to be modified to reduce the proportion of propionic acid in rumen volatile fatty acids (VFA). While it was shown a long time ago (Ensor, Shaw \& Tellechea, 1959) that the extent of cereal processing (steaming and flaking) increased the proportion of propionic acid in the rumen, attempts to modify the type of fermentation by cereal processing were at first unsuccessful. The use of pelleted rolled or pelleted whole barley made little or no difference to rumen $\mathrm{pH}$, type of fermentation or indeed food utilization (Ørskov, Fraser \& Gordon, 1974). This experiment did, however, pose the next question as to whether early weaned lambs could digest whole grains. The answer to this question was unequivocal, the experiment proving convincingly that early weaned lambs could digest and utilize whole barley grains $(\emptyset$ rskov, 
Fraser \& McHattie, 1974). Digestibility, particularly that of the fibre fraction, was even slightly greater than with processed grain. The rumen $\mathrm{pH}$ was maintained about one unit higher (about 6.1) with whole grain. This difference in $\mathrm{pH}$ had the result of completely eliminating papillary clumping, parakeratosis and hypertrophy, previously noted on the rumen wall of lambs receiving processed grain ( rskov, 1973). The reasons for the changes in rumen $\mathrm{pH}$ have been discussed and thought to be mainly attributed to the maintenance of a large surface area for absorption with feeding of whole grains.

Weston (1974) studied the digestion of whole wheat by lambs. Like other workers, he found it to be well digested and he made an interesting observation on the extent of the fractures of the whole grains swallowed by the sheep. Up to $70 \%$, of the whole grain arrived unfractured in the rumen, and when whole grains were incubated in the rumen for $48 \mathrm{~h}$ only $15^{\circ} \mathrm{g} / \mathrm{kg} \mathrm{DM}$ was lost. This observation would suggest that grain fracture occurs mainly during rumination, the duration of which was shown by $\emptyset$ rskov, Fraser \& Gordon (r974) to be doubled by feeding with whole rather than processed cereals.

The microflora was also different with feeding of whole grain (Mann \& Ørskov, 1975). The change in the rumen microflora caused a change in the type of rumen fermentation towards a lower propionic acid and a higher acetic acid proportion (Ørskov \& Fraser, 1972), an effect which was similar for barley, wheat, maize and oats. Digestibility and food utilization were virtually the same for whole and ground grain whether they were oats, barley, wheat or maize (Ørskov, Fraser \& McHattie, 1974). The only consistent difference was that gut contents were considerably greater with whole cereals, so that the carcass weight was slightly lower as a proportion of live weight. Similar observation on food utilization have been made

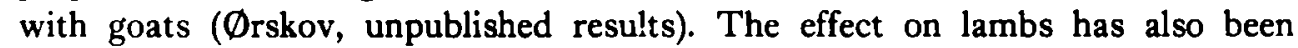
reported by Tait \& Bryant (I973), who found no difference in animal performance when wheat and barley were given in the whole or pelleted form. Whole wheat has also been used successfully as a drought feed for lambs in Australia (McManus, Reynolds \& Roberts, 1973).

The decrease in the proportion of propionic acid had the expected effect on the fatty acid composition of the subcutaneous fat. The proportions of odd-numbered and branched-chain fatty acids were reduced and stearic acid content increased, and as a consequence so was the firmness of the subcutaneous fat (Duncan et al. 1974).

\section{Cattle}

Most of the recent literature about sheep would indicate that any cost incurred in processing of cereal-based diets cannot be returned by an increase in utilization. This, however, cannot be said to apply directly to cattle. When whole cereals are fed to cattle there is usually an unacceptable depression in digestibility, though what is acceptable will in the final analysis depend on cost of processing. There seems to be a certain amount of disagreement about the amount of processing necessary or indeed desirable. When all-cereal diets were first introduced for cattle 
in the UK it was found that many animals bloated if the barley was finely ground but bloat was less of a problem with rolled barley (Preston, I963). It was thought that when some of the characteristics of roughage were retained no additional fibre was required (Geurin, Williamson, Thompson, Wilcke \& Bethke, 1959). The feeding of processed cereals to cattle has often given rise to ruminitis, as described by Fell et al. (1967). The thickening and clumping of rumen papillae was associated with the prevailing low $\mathrm{pH}$ since addition of sodium bicarbonate eliminated it (Kay, Fell \& Boyne, 1969). During the hypertrophy of the papillae, animal hairs became trapped, causing inflammatory reactions. The whole syndrome of ruminitis has been shown to be related to liver abscesses (Jensen, Deane, Cooper, Miller \& Graham, 1954).

The difference between sheep and cattle with respect to processing is probably a result both of the greater physical size of the latter which allows larger particles to pass the reticulo-omasal orifice and of a more thorough chewing and mastication by the sheep. That physical size may be important is supported by the observation that the depression in digestibility with feeding of whole grain is less with calves than with mature cattle. Nicholson, Gorrill \& Burgess (1974) showed that with mature cattle DM digestibility increased from 0.634 to 0.834 as a result of milling, while in another trial with calves, DM digestibility increased only from 0.722 to 0.790 . MacLeod, Macdearmid \& Kay (1972) showed that the digestibility for calves of whole barley was $0.73^{8}$ compared with 0.800 for rolled barley.

A large amount of work has recently been done in the USA on new methods of processing which include extruding, micronization, roasting, popping, etc. Hale (1973, 1975) has reviewed this information. It appears from his review that maximum processing, including steam treatment and flaking, is advocated, since it would increase the rumen fermentation of starch, and he concludes that processing improves the efficiency of utilization of starch by rumen micro-organisms or the animal, or both. Hale (1973) also refers to work indicating that a greater amount of VFA may be produced per unit of DM fermented. While the latter conclusion is not acceptable on theoretical grounds ( $\emptyset$ rskov, 1975), it is interesting that there seems to be emphasis on maximum processing. The difference is probably a result of the fact that sorghum (Sorghum vulgare Pers.) has been used in many of the USA studies. Sorghum seems to benefit more from processing than other grains. Maize also responds to processing; steam treatment of maize certainly increases the extent of rumen fermentation of starch (Armstrong, 1974). An increased amount of processing, which reduces particle size and increases rate of fermentation, would be expected to cause more severe lesions on the rumen wall of cattle. There is little information on this subject from the USA work; it would seem that the pathological changes in the rumen wall did not adversely affect food utilization.

It is still a matter for conjecture whether utilization of starch is increased if part of it is digested postruminally. Theoretically, losses of methane and heat should be lower if some starch, such as that in ground or kibbled maize, is digested postruminally. There is no evidence that in practice food utilization is improved by increasing the postruminal digestion of starch; in fact some reports referred to by 
Hale (1975) show the opposite, namely that increasing the extent of rumen fermentation, by flaking maize for example, improves food utilization.

When cattle are fed on cereals alone, the rapid rate of fermentation with resultant clumping of papillae, parakeratosis and the development of ruminitis is probably not very serious. Unlike sheep and goats, cattle do not seem to produce subcutaneous fats with abnormal proportions of odd and branched-chain fatty acids (G. A. Garton \& W. R. H. Duncan, unpublished results; see Garton, 1976), and as mentioned earlier, it has generally not been possible to link ruminitis to a decrease in animal performance. The method of processing of cereals for cattle, therefore, becomes dictated by economics. It is generally agreed that the extent of processing should be sufficient to avoid large reductions in digestibility. Further processing to increase the extent and rate of rumen fermentation must be of doubtful value or even undesirable.

\section{The effect of cereal-based supplements on voluntary intake and digestion of roughage}

With a rumen of $\mathrm{pH}$ of less than 5.8 to 6.0 , the growth rate of cellulolytic bacteria is inhibited (Hungate, 1966) and such acidity is found when processed concentrates are fed.

When cereal-based diets are fed as supplements to a roughage-based diet they are usually given in restricted quantities once or twice daily. The diurnal variations in rumen $\mathrm{pH}$ when whole or processed grains are given in restricted amounts are illustrated in Fig. I, which is calculated from results obtained by $\emptyset$ rskov \& Fraser (1975). The low $\mathrm{pH}$ following the feeding of processed concentrate was not unexpected. However, the difference in rumen $\mathrm{pH}$ when whole barley was given was thought to have interesting implications for the use of cereal-based supplements by ruminants, because it has often been observed that cereal supplements caused an equivalent reduction in roughage intake (Blaxter, Wainman \& Wilson, 1961 ; Lonsdale, Poutiainen \& Tayler, 1971), so that the total DM intake

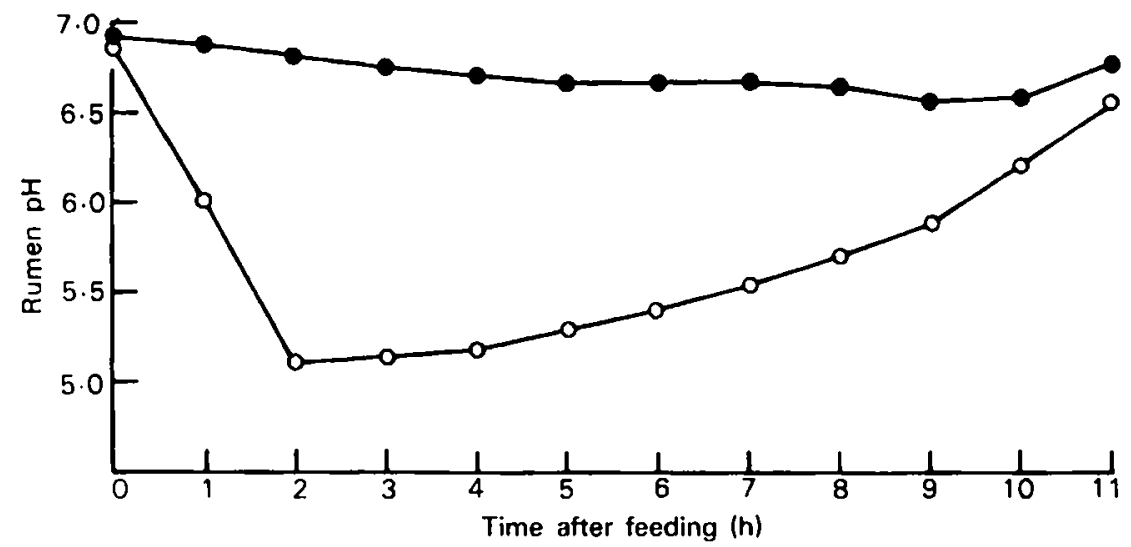

Fig. I. The effect of time of feeding on rumen $\mathrm{pH}$ in lambs given diets based on whole (O) or rolled and pelleted $(O)$ barley, in two equal meals daily at 08.00 and 20.00 hours. (Calculated from results of Orskov \& Fraser (1975).) 
was not always altered. This effect has been thought to result from a reduction in rate of cellulose digestion as both Head (1953) and MacRae \& Armstrong (1 969) showed a reduction in cellulose digestibility.

Studies by Mann \& $\emptyset$ rskov (1 975) showed that lambs fed on whole barley had on average $1 \times 10^{6}$ viable cellulolytic bacteria/ $\mathrm{ml}$ of rumen contents, while lambs given processed barley had only $5 \times 10^{3}$. This observation was substantiated by quite large differences in the rate of digestion of dried grass when it was incubated in Dacron bags suspended in the rumen of sheep receiving either whole or processed grain. After $24 \mathrm{~h}$ of incubation $625 \mathrm{mg} / \mathrm{g}$ had disappeared in sheep given whole grain but only $425 \mathrm{mg} / \mathrm{g}$ had disappeared in sheep receiving processed grain (Ørskov \& Fraser, 1975). Accordingly it was expected that processing of cereals might influence the voluntary intake of roughage. In order to test this hypothesis lambs were given dried grass $a d$ lib. and once daily a supplement of either 25 or 50 $\mathrm{g}$ whole or rolled and pelleted grains/kg body-weight ${ }^{0.75}$. The low level of cereal supplementation caused a depression in intake of grass and there was no difference between whole and processed grain. At the higher level of supplementation, however, intake of dried grass was reduced much more by processed than by whole barley. The lack of any difference at the low level of supplementation is supported by results obtained by Chimwano, Ørskov \& Stewart (1976), which showed that a low level of supplementation with processed cereals had little effect on rate of cellulose digestion. There is clear evidence, however, that the extent of processing of cereal supplements could directly influence the voluntary intake of the roughage part of the diet at higher levels of supplementation. This principle is similar for both cattle and sheep and it may be that processing methods such as steaming, flaking etc. that are aimed at increasing rate of fermentation may adversely infuence digestion if the processed cereals are given as supplements to roughagebased diets.

\section{Supplementing grains with other nutrients}

Grain used as the sole feedstuff for ruminants contains insufficient nitrogen to meet the rumen microbial need ( rskov, Fraser \& McDonald, 1972), and is also inadequate in several minerals, trace elements and vitamins. This became a problem when it was desired to feed sheep on whole grains alone. It is possible to include pellets containing the necessary supplements of protein, vitamins and minerals with the whole grain, but they need to be small to mix satisfactorily. In several experiments (e.g. Fraser \& Ørskov, 1974), high-protein pellets have been included at a rate of $100 \mathrm{~g} / 900 \mathrm{~g}$ cereal. For many production systems the need for protein by the animals is met by the contribution of microbial and undegraded cereal protein and there is no need for further protein supplementation (Ørskov, 1975). In systems where the need is not met, e.g. early weaning and early lactation, the protein supplement may be given so that the rumen is by-passed, or it may be chemically protected from rumen degradation.

A problem occurred when it was desired to by-pass the rumen with the protein supplements in systems where whole grains were fed to lambs. In unpublished 
work by A.Z. Mehrez \& E.R. Ørskov, the voluntary intake of whole barley and maize grains was low because the need for $\mathrm{NH}_{3}$ by the micro-organisms for a maximum rate of degradation was not met. It was desirable to include a source of non-protein-N but addition of urea crystals to whole grains proved impossible owing to segregation. This problem was solved when it was found that urea could be completely absorbed in whole grain when it was included as a saturated solution. Complete absorption into grains was shown to occur with barley, maize, oats and wheat and no crystals were reformed. Since urea is highly soluble (approx. $50: 50, \mathrm{w} / \mathrm{v}$ ) the inclusion of about $10 \mathrm{~g}$ moisture/ $\mathrm{kg}$ grain per $10 \mathrm{~g}$ urea is generally acceptable. This method of inclusion not only prevents palatability problems and ensures a homogeneous incorporation, but gives a subsequent slower release of $\mathrm{NH}_{3}$ in the rumen (Ørskov, Smart \& Mehrez, 1975). Recent work has further established that when soluble forms are used, the necessary minerals and vitamins can also be absorbed in the whole grains, thus making a complete food.

\section{Conclusions}

It would appear from a review of literature and from the results of recent work that processing of cereals should in general be employed only to the extent necessary to avoid an unacceptable depression in digestibility.

For lambs, goats and sheep, processing of cereals is undesirable. If cereal-based diets are fed as sole feedstuffs, processing can give rise to ruminitis and soft, unacceptable carcass fat. When cereal-based diets are given as supplements to roughage, processing can cause a depression in rumen $\mathrm{pH}$ which in turn depresses rate of cellulose digestion and consequent voluntary intake of roughages.

For cattle, some processing is required to avoid a reduction in digestibility. The processing required appears to be greater for sorghum and maize than for other cereals. Processes which achieve the minimum rupture of the grain should be developed to avoid pathological changes in the rumen wall and to ensure an efficient digestion of roughage.

\section{REFERENCES}

Andrews, R. P. \& Ørskov, E. R. (1970). f. agric. Sci., Camb. 75, 11.

Armsby, H. P. (1917). The Nutrition of Farm Animals. New York: McMillan.

Armstrong, D. G. (1972). In Cereal Processing and Digestion. London: US Feed Grains Council. Armstrong, D. G. (1974). In Cereal Supply and Utilization, p. 21. London: US Feed Grains Council.

Blaxter, K. L., Wainman, F. W. \& Wilson, R. S. (1961). Anim. Prod. 3, 5 I.

Burt, A. W. A. (1973). Proc. Nutr. Soc. 32, 3 I.

Chimwano, A. M., Ørskov, E. R. \& Stewart, C. S. (1976). Proc. Nutr. Soc. 35, 101 A.

Duncan, W. R. H., Orskov, E. R., Fraser, C. \& Garton, G. A. (1974). Br. F. Nutr. 32, 7 I.

Duncan, W. R. H., Ørskov, E. R. \& Garton, G. A. (1972). Proc. Nutr. Soc. 31, IgA.

Duncan, W. R. H., Ørskov, E. R. \& Garton, G. A. (1976). Proc. Nutr. Soc. 35, $89 \mathrm{~A}$.

Ensor, W. L., Shaw, J. C. \& Tellechea, H. F. (1959). F. Dairy Sci. 42, 189.

Fell, B. F., Kay, M., Ørskov, E. R., Boyne, R. \& Walker, T. (1972). Res. vet. Sci. 13, 30.

Fell, B. F., Kay, M. \& Walker, T. (1967). Vet. Rec. 81, 715.

Fraser, C. \& Ørskov, E. R. (1974). Anim. Prod. 18, 75 .

Garton, G. A. (1976). Rep. Rowett Inst. 31, 124. 
Gay, P. (1896). Quoted by Armsby (1917).

Geurin, H. P., Williamson, J. L., Thompson, J. C., Wilcke, H. L. \& Bethke, R. N. (1959). F. Anim. Sci. $18,1489$.

Hale, W. H. (1973). F. Anim. Sci. 37, 1075.

Hale, W. H. (1975). Proc. Georgia Nutr. Conf. 1975, p. 131.

Head, M. J. (1953). F. agric. Sci., Camb. 43, 28 r.

Hungate, R. E. (1966). The Rumen and its Microbes. London and New York: Academic Press. Jensen, R., Deane, H. M., Cooper, L. F., Miller, V. A. \& Graham, W. R. (1954). Am. f. vet. Res. I5, 202.

Kay, M., Fell, B. F. \& Boyne, R. (1969). Res. vet. Sci. 10, 181 .

Kellner, O. (1908). The Scientific Feeding of Animals [Translated by W. Goodwin]. London: Duckworth.

Lonsdale, C. R., Poutiainen, E. R. \& Tayler, J. C. (1971). Anim. Prod. 13, 461.

MacLeod, N. A., Macdearmid, A. \& Kay, M. (1972). Anim. Prod. 14, III.

McManus, W. R., Reynolds, J. A. \& Roberts, E. M. (1973). Aust. F. agric. Res. $24,413$.

MacRae, J. C. \& Armstrong, D. G. (Ig69). Br. F. Nutr. 23, 377.

Mann, S. O. \& Qrskov, E. R. (1975). Proc. Nutr. Soc. 34, 63A.

Morrison, F. B. (1948). Feeds and Feeding, 2 Ist ed. Clinton, Iowa: The Morrison Publishing Co.

Morton, J. C. (1855). Cyclopedia of Agriculture. London: Blackie \& Son.

Nicholson, J. W. G., Gorrill, A. D. \& Burgess, P. L. (1971). Can. J. Anim. Sci. 51, 697.

Ørskov, E. R. (1973). Res. vet. Sci. 14, 110.

Ørskov, E. R. (1975). Wld Rev. Nutr. Diet. 22, 152.

Orskov, E. R. \& Fraser, C. (1972). Proc. Nutr. Soc. 31, rorA.

Ørskov, E. R. \& Fraser, C. (1975). Br. Y. Nutr. 34, 493,

Orskov, E. R., Fraser, C., Gill, J. C. \& Corse, E. L. (1971). Anim. Prod. 13, 485.

Ørskov, E. R., Fraser, C. \& Gordon, J. G. (1974). Br. f. Nutr. 32, 59.

Orskov, E. R., Fraser, C. \& McDonald, I. (1972). Br. Y. Nutr. 27, 49 I.

Ørskov, E. R., Fraser, C. \& McHattie, I. (1974). Anim. Prod. 18, 85 .

Ørskov, E. R., Smart, R. I. \& Mehrez, A. Z. (I975). F. agric. Sci., Camb. 83, 799.

Philip, E. B., Preston, T. R. \& Greenhalgh, I. (1964). Anim. Prod. 6, 261.

Preston, T. R. (1963). Vet. Rec. 75, 1399.

Scaife, J. R. \& Garton, G. A. (I975). Biochem. Soc. Trans. 3, rorr.

Tait, R. M. \& Bryant, R. G. (1973). Can. J. Anim. Sci. 53, 89.

Waldo, D. R. (1973). J. Anim. Sci. 37, 1062.

Weston, R. H. (1974). Aust. f. agric. Res. 25, 349. 